\title{
On (non-)compatibility of genitive partitive and imperfective in Russian: a corpus study
}

\author{
Oksana Iu. Chuikova \\ Herzen State Pedagogical University of Russia \\ oxana.chuykova@gmail.com
}

\begin{abstract}
The paper provides the results of the study of the use of the genitive case with partitive semantics as the means of direct object marking within imperfective verbs in Russian. The genitive partitive is traditionally claimed to be compatible with perfective verbs and as an exception with imperfective verbs used as the substitution for perfective verbs in neutralization contexts. The analysis of the data from the Russian National Corpus and the Russian-language Internet shows that the use of the genitive partitive within imperfective verbs is neither rare nor marginal. The compatibility level of the genitive and imperfective aspectual correlates of prefixed perfective verbs is dependent on the imperfectivability level and frequency. The use of the genitive partitive is sensitive to the semantics of the imperfective, however, it means the coverage of a broader range of phenomena than it is traditionally assumed. Although the use of the genitive partitive is mostly restricted to neutralization contexts such as iterativity and historical present, a number of gradual achievement imperfective verbs with progressive semantics as well as verbs that refer to constant situations are compatible with the genitive partitive.
\end{abstract}

Ключевые слова: Russian language, verbal aspect, Aktionsarten, direct object, partitive genitive case, perfective verbs, imperfective verbs, corpus study

DOI: $10.28995 / 2075-7182-2021-20-162-178$

\section{К вопросу о (не)сочетаемости родительного партитивного и несовершенного вида в русском языке: корпусное исследование}

\author{
Оксана Юрьевна Чуйкова \\ Российский государственный педагогический \\ университет им. А. И. Герцена \\ oxana. chuykova@gmail.com
}

\begin{abstract}
Аннотация
В статье приводятся результаты исследования сочетаемости родительного падежа с партитивной семантикой как средства оформления прямого дополнения и несовершенного вида глагола в русском языке. В литературе распространена точка зрения, согласно которой употребление родительного партитивного возможно только при перфективных глаголах и как исключение при имперфективных глаголах в контекстах нейтрализации видового противопоставления. Анализ материала Национального корпуса русского языка показывает, что употребление родительного партитивного при имперфективных глаголах не представляет собой редкое или маргинальное явление. Уровень сочетаемости родительного партитивного и имперфективных видовых коррелятов приставочных глаголов определяется уровнем имперфективируемости и собственной частотностью глагольных лексем. Употребление родительного партитивного падежа чувствительно к частным значениям несовершенного вида, однако круг явлений оказывается шире, чем традиционно обсуждается в литературе. Несмотря на преимущественное употребление в контекстах нейтрализации, таких как итеративность и настоящее историческое, употребление родительного партитивного наблюдается также при градационных глаголах в актуально-длительном значении и глаголах, реферирующих к постоянным ситуациям.

Ключевые слова: русский язык, глагольный вид, способы действия, прямое дополнение, родительный партитивный падеж, перфективные глаголы, имперфективные глаголы, корпусное исследование
\end{abstract}




\section{1 Вводные замечания}

В литературе распространена точка зрения, согласно которой употребление родительного (далеех- род.) падежа с партитивным значением возможно при глаголах совершенного вида (далеех- СВ) и невозможно при глаголах несовершенного вида (далее - НCВ) [20], [12: 182190], [13], [6: 249], [18: 39], cp. (1)-(2):

(1) Дурасиков помолчал, прокашлялся, выпил воды из стакана и сказал: «Тогда ладно...» [Дина Рубина. Медная шкатулка (2011-2015)]

(2) Хальдор поднялся к себе и долго, шумно пил воду. [Елена Хаецкая. Хальдор из светлого города (1997)] (*воды)

В ряде работ [20: 2236], [12: 182] делается оговорка, согласно которой запрет на род. падеж в позиции прямого дополнения действует лишь в отношении случаев использования НСВ в актуально-длительном значении и не распространяется на случаи употреблении НСВ в итеративном значении или в настоящем историческом, то есть в контекстах нейтрализации видового противопоставления, где НСВ является функциональной заменой СВ. При этом в случае вхождения глагола СВ в «видовую тройку» в контекстах нейтрализации используется вторичный имперфектив [21: 50], см. (3).

(3) После репетиций мы шли напротив в «Артистик», выпивали коньячку и продолжали свои разговоры, беседы. [Михаил Рощин, Татьяна Бутрова. Драматургия и проза жизни // «Октябрь», 2003]

Несмотря на то, что проблематика сочетаемости НСВ и род. падежа неоднократно затрагивалась в литературе, вопрос о степени распространенности таких сочетаний (с точки зрения как лексического разнообразия глаголов НСB, так и соотношения род. и вин. падежей) до сих пор подробно не рассматривался. В работе последовательно анализируется возможность употребления род. партитивного при глаголах НСВ, являющихся видовыми коррелятами глаголов СВ, способных к генитивному управлению. Цель исследования - проверка на корпусных данных и уточнение представлений о наличии зависимости между грамматическим значением вида и допустимостью оформления прямого дополнения род. падежом.

\section{2 Материал и методика исследования}

Для анализа сочетаемости глаголов с род. падежом прямого дополнения и его соотношения с формой вин. падежа была реализована следующая исследовательская процедура.

По Малому академическому словарю (далее - МАC) [3] был получен список глагольных лексем $\mathrm{CB}$, для которых в рамках указанного словаря зафиксирована возможность управления род. падежом. К анализу привлекались более или менее объемные (более 10 лексем) морфологические группы глаголов $\mathrm{CB}$, для которых характерно употребление с род. партитивным (всего 531 лексема): глаголы с префиксами по- - 51 лексема, $н a-$ - 372 лексемы, $n о д-~-48$ лексем, $n p u$ - -27 лексем, до- - 19 лексем, om- - 14 лексем. Как представляется, рассмотрение групп глаголов, объединенных определенными морфемными показателями, позволяет, с одной стороны, получить разнообразный языковой материал для анализа, с другой - выявить возможные сходства и различия в употреблении глаголов, входящих в разные группы.

В рамках исследования принята восходящая к С. И. Карцевскому [10] точка зрения, согласно которой тождество лексического значения возможно лишь в суффиксальных парах, где имперфективный коррелят образован от перфективного глагола при помощи суффикса -(bl/u)вa- (реже -a-). Для каждой перфективной глагольной лексемы, с опорой на результаты исследования имперфективируемости русских префиксальных глаголов (см. [9], а также базу данных по имперфективируемости: http://www.rusimpdb.ru) определялся имперфективный видовой коррелят (при его наличии), напр., добавить - добавлять, надергать - надергивать. При анализе учитывались как представленные в МАС конвенциональные имперфективные корреляты, так и глаголы, отсутствующие в словаре, но зафиксированные по данным Национального 
корпуса русского языка (далее - НКРЯ) [17] и русскоязычного сегмента сети Интернет (рунет), напр., накуковать - накуковывать. Кроме того, вслед за рядом авторов [14: 364], [4], [7], принято решение считать глаголы прерывисто-смягчительного способа действия (далее - СД) результатом имперфективации делимитативов, т. е. объединять в видовые пары такие глаголы, как попить - попивать.

По данным основного подкорпуса НКРЯ методом ручной выборки составлен перечень и подсчитано количество всех зафиксированных в корпусе употреблений глаголов СВ и соответствующих им глаголов НСВ с дополнением в форме род. и вин. падежей. Поскольку употребление род. партитивного в позиции прямого дополнения возможно только в тех случаях, когда объект выражен кумулятивной именной группой (существительным с вещественной, реже отвлеченной, семантикой либо существительным в множественном числе, напр., попить воды, прибавить скорости, нарубить дров, см. [2: 83]), при подсчете случаев употребления вин. падежа также учитывались только примеры с кумулятивными именами. В базу данных не включались случаи употребления падежных форм в отрицательных контекстах и примеры, где падежная форма не определяется однозначно: употребления с несклоняемыми существительными (напр., кофе) в отсутствие определяющих слов либо иных средств, снимающих неоднозначность, а также примеры с одушевленными объектами, где наблюдается формальное совпадение род. и вин. падежей (учитывались сочетания типа пострелять дичи, но не пострелять уток).

При отсутствии примеров в НКРЯ, осуществлялся дополнительный поиск примеров в рунете.

\section{3 Анализ результатов}

В настоящей работе рассматриваются следующие аспекты, связанные с употреблением род. партитивного при глаголах НСВ: способность к употреблению с род. партитивным для глаголов СВ и НСВ в сопоставлении с данными об имперфективируемости префиксальных перфективов (раздел 3.1), количественные данные о соотношении род. и вин. падежей при глаголах СВ и НСВ (3.2), семантика НСВ и способность к употреблению с род. партитивным (3.3).

\section{1 Способность к употреблению с родительным партитивным и имперфективируемость}

В Табл. 1 ниже приведены данные (в абсолютных числах) о соотношении общего количества глагольных лексем с отмеченной в МАС способностью к управлению род. падежом (531 лексема) и количества глаголов СВ и НСВ, для которых по данным НКРЯ и рунета зафиксированы примеры употребления с формой род. партитивного в позиции прямого дополнения. Употребление с род. партитивным считается зафиксированным в случае обнаружения в анализируемом источнике (НКРЯ либо рунете) по крайней мере одного примера соответствующего функционирования.

Оценивая общее по всем рассматриваемым приставочным группам количество глагольных лексем НСВ, демонстрирующих случаи управления род. падежом, можно сделать вывод что такое употребление для глаголов НСВ не является редким или маргинальным: по суммарным данным НКРЯ и рунета сочетание с род. падежом наблюдается для 252 глаголов НСВ, что составляет $53,85 \%$ от общего количества лексем СВ, реализующих способность к употреблению с род. падежом.

\begin{tabular}{|c|c|c|c|c|c|}
\hline & $\begin{array}{l}\text { Количество } \\
\text { лексем СВ } \\
\text { (по МАС) }\end{array}$ & $\begin{array}{l}\text { СВ с род. } \\
\text { партитивным } \\
\text { по (НКРЯ) }\end{array}$ & $\begin{array}{l}\text { СВ с род. } \\
\text { партитивным } \\
\text { (НКРЯ+рунет) }\end{array}$ & $\begin{array}{l}\text { НСВ с род. } \\
\text { партитивным } \\
\text { (НКРЯ) }\end{array}$ & $\begin{array}{l}\text { НСВ с род. } \\
\text { партитивным } \\
\text { (НКРЯ+рунет) }\end{array}$ \\
\hline no- & 51 & 46 & 51 & 2 & 10 \\
\hline Ha- & 372 & 257 & 326 & 57 & 168 \\
\hline под- & 48 & 27 & 36 & 15 & 30 \\
\hline при- & 27 & 21 & 24 & 16 & 18 \\
\hline om- & 19 & 11 & 17 & 8 & 15 \\
\hline до- & 14 & 11 & 13 & 7 & 11 \\
\hline Всего & 531 & 373 & 468 & 105 & 252 \\
\hline
\end{tabular}

Таблица 1: Количество лексем, употребляемых в сочетании с род. партитивным (данные МАС, НКРЯ и рунета) 
Несмотря на то, что имперфективные глаголы показывают далекий от нулевого уровень сочетаемости с род. партитивным, сниженные показатели относительно данных для перфективных глаголов требуют объяснения.

Для наглядности представим приведенные выше данные в виде диаграммы, демонстрирующей относительные показатели реализованной способности к употреблению с род. партитивным глагольных лексем СВ, для которых такая возможность зафиксирована в МАС, и их коррелятов НСВ.

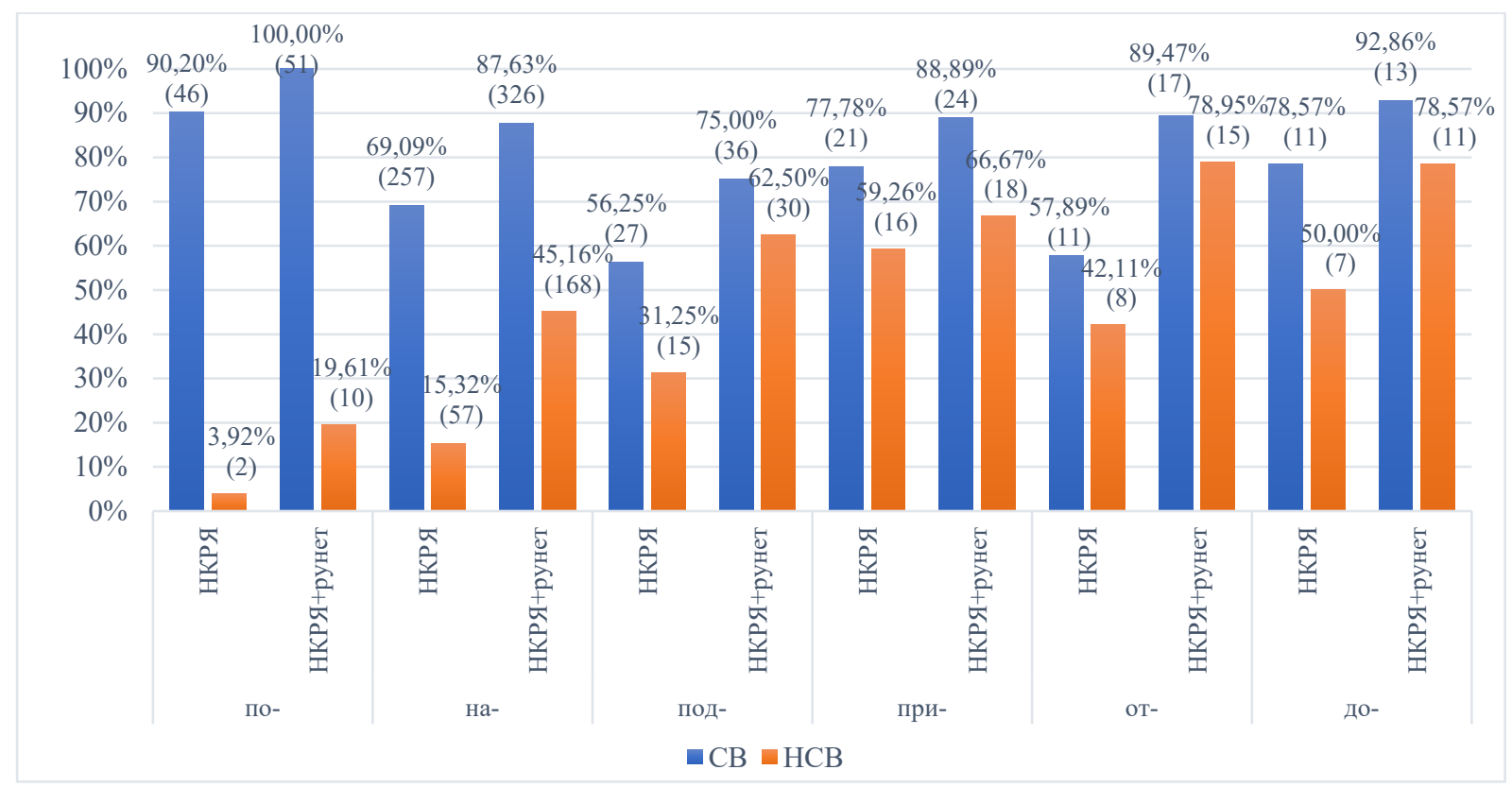

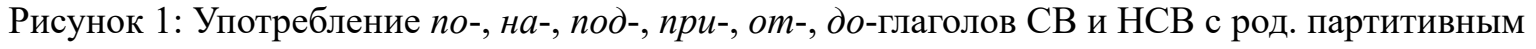
(относительные данные)

Рис. 1 показывает, что способность к употреблению с род. партитивным неодинакова у различных с точки зрения морфемного состава глаголов НСВ.

По-глаголь. Наибольшая разница между количеством глаголов СВ, для которых зафиксированы примеры употребления с род. партитивным, и аналогичными данными для глаголов НСВ, наблюдается в группе по-глаголов. Суммарные данные НКРЯ и рунета показывают, что для всех перфективных по-глаголов с отмеченной в МАС способностью к генитивному управлению обнаруживаются соответствующие примеры употребления. При этом использование род. падежа наблюдается только при 10 глаголах НСВ, что составляет около 19,6 \% от общего количества глаголов СВ в выборке (см. Рис. 1); по данным НКРЯ - посыпа́ть, попивать (см. (4)-(5)), по данным рунета — пожевывать, покапывать, покушивать, понюхивать, похлебывать, понавешивать, понадельвать, понастраивать (см., напр., (6)).

(4) Лазунка часто встает, шевелит угли костра да лопаткой посыпает сырого песку, чтоб хозяин не сжег сапоги... [А. П. Чапыгин. Разин Степан (1927)]

(5) Мама Маринина снова попивает портвешку, хотя меру все-таки знает, может, по Марининым молитвам. [Майя Кучерская. Современный патерик: чтение для впавших в уныние (2004)]

(6) В Балашихе если что, в 90-е таких домов не было. Это в конце нулевых и в 10-е годы стали понастраивать муравейников. (https://brstate.com/v/12V8yIeCkKClq4s/mypopali.html)

Различие в количестве по-глаголов СВ и НСВ, реализующих способность к управлению род. партитивным, может объясняться общим низким уровнем имперфективируемости данной префиксальной группы, см. [8], [1]. Следует отметить, что большинство перфективных по-глаголов, 
для которых наблюдается сочетаемость с род. партитивным, составляют лексемы, относящиеся к СД: делимитативному (25 лексем), аттенуативному (3 лексемы), кумулятивно-дистрибутивному (разновидности дистрибутивного СД) (14 лексем), поэтому при сопоставлении данных более корректно рассматривать показатели имперфективируемости СД с префиксом nо-. В [1] показано, что уровни имперфективируемости аттенуативного и дистрибутивного СД значительно снижены по сравнению с данными по префиксальной группе в целом, в то время как делимитативный СД демонстрирует сопоставимый с общим по префиксальной группе (и даже несколько повышенный) уровень имперфективируемости (по суммарным данным МАC+рунет: дистрибутивный СД - 36,9\%, аттенуативный СД - 48,39\%, делимитативный СД - 73,03\%, общий уровень имперфективируемости по-глаголов - 65,47\% и $68,92 \%$ по максимальной и минимальной выборкам соответственно). Из 25 делимитативных лексем в пределах рассматриваемой выборки глаголов, способных к употреблению с родительным падежом, 18 (72\%) имеют имперфективные корреляты, только для 6 из которых обнаруживаются примеры генитивного управления. Можно предположить, что невысокая доля имперфективных глаголов, демонстрирующих сочетаемость с род. падежом, на фоне данных о высоком уровне имперфективируемости делимитативного СД в целом, объясняется тем, что несмотря на наблюдаемую композициональность семантики глаголов прерывисто-смягчительного СД (префикс по- указывает на делимитативную семантику, а суффикс -ьвва-/-ива- — на итеративность, см. [14: 364], [1: 162]), пары типа попить - попивать не в полной мере удовлетворяют критерию видовой парности, а именно, глагол НСВ не способен служить заменой $\mathrm{CB}$, например, в таком контексте нейтрализации видового противопоставления, как настоящее историческое.

Ha-глаголы. Наиболее многочисленную группу глаголов, для которых в МАС зафиксирована возможность управления род. падежом, составляют глагольные лексемы с префиксом на- - 372 лексемы. В литературе отмечается практически обязательное оформление род. партитивным дополнения при глаголах с префиксом $н a-$, в частности, для входящего в состав данной префиксальной группы кумулятивного СД [5], [15], [16].

Глаголы с префиксом $н a-$ и семантикой накопления можно разделить на два типа: 1. «прототипическое» значение кумулятивного СД, в соответствии с определением М. А. Шелякина, «действия, направленные на достижение значительного количества одних и тех же результатов путем многократного осуществления действия исходного глагола» [19: 144], см. (7); 2. значение простого накопления объекта, соответствующее определению кумулятивного СД в [21: 114]: «Глаголы этого класса обозначают “накопление результата” действия», см. (8).

(7) Шишек накидал, веток сухих наломал - и вот тебе топливо», - рассказывает Дмитрий. [коллективный. Неделя. Герои // «Огонек», 2014]

(8) Когда он приподнимал голову, чтобы набрать воздуху, в его глазах плясали два маленьких костра. [Фазиль Искандер. Первое дело (1956)]

Рис. 1 показывает, что примеры употребления с род. падежом фиксируются в анализируемых источниках для 168 имперфективных лексем с префиксом на-, что составляет немногим меньше половины $(45,16 \%)$ от общего количества перфективных лексем, для которых в МАС дается указание на возможность генитивного управления, при этом наблюдается существенное (практически трехкратное: в абсолютных числах — с 57 до 168) возрастание доли лексем НСВ, демонстрирующих примеры сочетания с род. падежом по данным рунета по сравнению с показателями НКРЯ. Как представляется, относительно низкая доля глаголов НСВ с префиксом на-, для которых фиксируются примеры употребления с род. падежом, может объясняться не ограничением на сочетаемость значений род. партитивного и $\mathrm{HCB}$, а особенностями функционирования, в частности, фактической неупотребительностью конкретных глаголов кумулятивного СД. Приведем несколько наблюдений.

Из Табл. 1 и Рис. 1 видно, что из 372 глагольных лексем СВ, для которых возможность употребления с род. падежом отмечена в МАC, 326 (87,63\%) демонстрируют соответствующие случаи употребления в исследуемых источниках. При этом следует отметить, что глаголы СВ (46 лексем, $12,37 \%$ ), для которых не зафиксированы примеры употребления с родительным партитивным, либо не демонстрируют случаев употребления ни с одной из падежных форм, либо 
показывают низкую частотность и представлены единичными случаями употребления с винительным падежом. Корреляты НСВ таких глаголов также не употребляются в НКРЯ и рунете.

М. А. Шелякин отмечает, что имперфективные варианты глаголов кумулятивного СД встречаются изредка и только со значением многократности [19: 144]. Однако данные [1: 168] демонстрируют относительно высокий уровень имперфективируемости глаголов кумулятивного СД, по суммарным данным МАC и рунета достигающий $81,63 \%$. В рамках выборки, включающей 326 глаголов, для которых в НКРЯ и рунете фиксируются случаи употребления с родительным партитивным, имперфективируемость устанавливается на уровне $91,72 \%$, или 299 лексем по суммарным данным МАC+рунет (по МАC - 71,47\%, 233 лексемы), при этом для 91 лексемы не обнаруживается однозначно определяемых примеров употребления как род., так вин. падежа. Из оставшихся 208 имперфективных лексем 168, или 80,77\%, демонстрируют примеры употребления с род. партитивным. Отметим, что не зафиксированные в МАС, но образованные по регулярной модели неконвенциональные корреляты глаголов кумулятивного СД демонстрируют сочетаемость с род. падежом, см. (9)-(10).

(9) А мы,помню школярами кохды были - салфетки сворачивали в несколько раз треуголкой и яки зверско-голодная моль,ножницами дырок в ней накрамсывали сикась-накось, а потома - разворачиваешь и дивные «снежинки» получались с узорами усякими. (http://www.ozersk74.ru/news/usernews/219211)

(10) Но да, уговаривать и наобещивать гор - это очень не полезное дело. (https://www.b17.ru/forum/topic.php?id=114081\&p=22)

Таким образом, практически реализуемая способность видовых коррелятов лексем кумулятивного СД с префиксом на- зависит как от зафиксированного уровня имперфективируемости, так и от фактической употребительности перфективных глаголов и их имперфективных коррелятов. В случае, если у глагола НСВ фиксируются случаи употребления в НКРЯ либо рунете, в большинстве случаев наблюдается также оформление прямого дополнения родительным падежом.

Под-, при-, до- $\boldsymbol{u}$ от-глаголы. Основную часть глаголов с префиксами под-, при-, до- и отсоставляют выделяемые в классификации СД М. А. Шелякина [19] (и отсутствующие, например, в классификации, изложенной в [21]) комплетивно-партитивный СД с префиксами под- (46 из 48, 95,83\%): подкинуть, подкопить, при- (19 из 27, 70,37\%): придать, приработать, до- (9 из 14, 64,3\%): добавить, добрать, отделительно-партитивный СД с префиксом от- (19 из 19, 100\%): отлить, отсыпать.

Как видно из Табл. 1, в рамках приставочных групп с префиксами под-, npu-, до- и om- доли глаголов НСВ, демонстрирующих примеры употребления с родительным падежом в НКРЯ и рунете, по отношению к данным для глаголов СВ, выше, чем в рассмотренных ранее группах с префиксами no- и $н a-$. В первую очередь, это может объясняться более высоким уровнем имперфективируемости глаголов с префиксами под-, $n p u-$, до- и om-. Глаголы перечисленных приставочных групп характеризуются высоким уровнем имперфективируемости. Согласно МАС, в рамках рассматриваемых выборок парными являются 43 из 48 (89,6\%) глаголов с префиксом под-, 26 из 27 (96,3\%) - с префиксом при-, 14 из 14 (100\%) - с префиксом до-, 16 из 19 (84,2\%) - с префиксом om-. При привлечении данных НКРЯ и рунета имперфективируемость во всех группах достигает тотального уровня.

Приведенные данные позволяют сделать вывод, что доля НСВ, способных к употреблению с род. партитивным в рамках различных префиксальных групп, в основном определяется, во-первых, количеством глаголов СВ, демонстрирующих примеры использования с род. партитивным в НКРЯ и рунете, во-вторых, уровнем имперфективируемости, наблюдаемым для всей приставочной группы в целом и для входящих в нее СД в частности. Отклонение от данной тенденции, наблюдаемое для группы делимитативных по-глаголов можно связать с особенностями видового противопоставления, устанавливаемого в парах «делимитативный СД - прерывисто-смягчительный СД». 


\section{2 Родительный падеж при глаголах СВ и НСВ: количественные данные}

Анализ количественного соотношения форм род. и вин. падежей при 105 глагольных лексемах $\mathrm{HCB}$, для которых в НКРЯ зафиксированы случаи употребления с род. партитивным, и сопоставление полученных данных с показателями для соответствующих глаголов СВ показывает, что выбор род. падежа для оформления прямого дополнения при глаголах $\mathrm{CB}$ осуществляется чаще, чем при глаголах НСВ. В Приложениях А-Д приводятся данные о количестве обнаруженных в основном подкорпусе НКРЯ примеров употребления род. и вин. падежей для каждого из 105 имперфективных глаголов и их перфективных коррелятов. Тенденция к преобладанию винительного падежа при глаголах НСВ наблюдается как для выборки в целом, так и для приставочных групп в отдельности (по показателям средних значений, медианам, стандартному отклонению). Данные о соотношении частот по всем 105 глаголам приводятся на Рис. $2^{1}$, в то время как Табл. 2. показывает наличие статистически значимой зависимости между значением вида и падежным оформлением прямого дополнения. Аналогичные данные для каждой префиксальной группы приводятся в Приложениях.

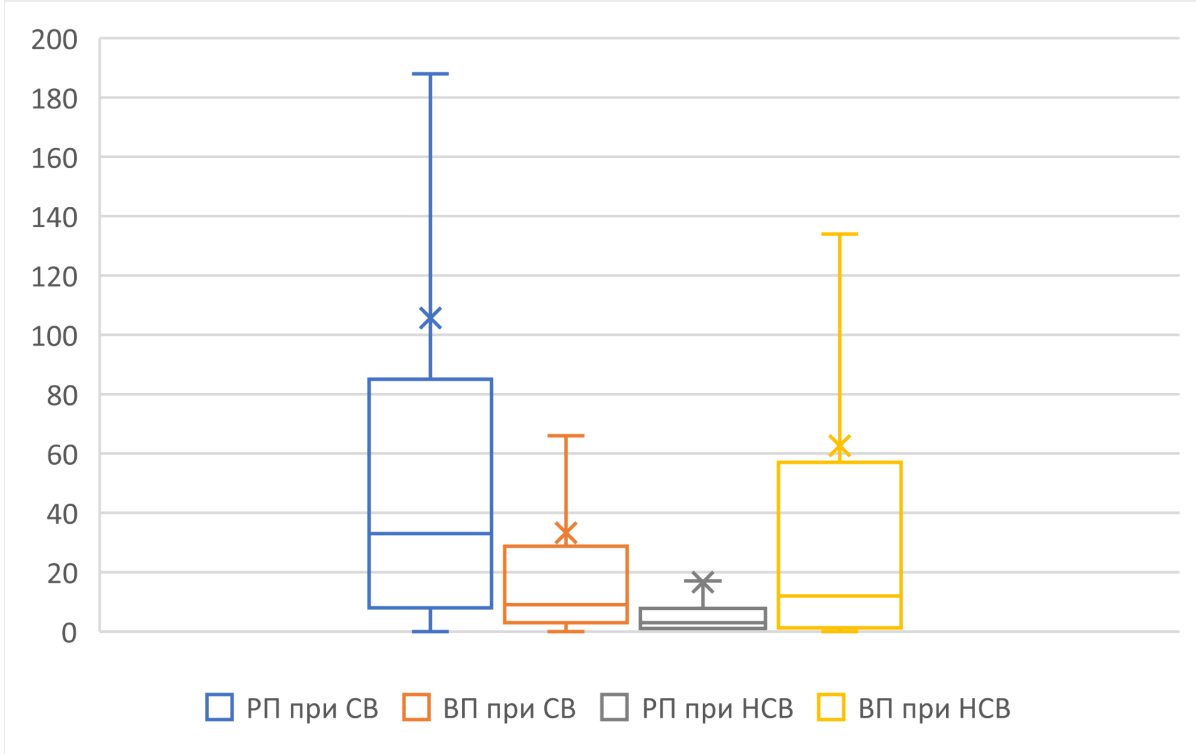

Рисунок 2: Частоты конструкций с родительным и винительным падежами при СВ и НСВ

\begin{tabular}{|l|ll|l|}
\hline & РП & ВП & Всего \\
\hline CВ & 10989 & 3458 & 14447 \\
НСВ & 1729 & 6515 & 8244 \\
\hline Всего & 12718 & 9973 & 22691 \\
\hline
\end{tabular}

Различие статистически значимо: $\chi^{2}=6464,608, \mathrm{p}<<0,01$.

Таблица 2: Распределение конструкций с родительным и винительным падежами при глаголах СВ и НСB

Различия в соотношении род. и вин. падежей при глаголах $\mathrm{CB}$ и НСВ может объясняться упоминаемыми в литературе ограничениями на сочетаемость род. партитивного с определенными частными значениями $\mathrm{HCB}$, в частности, с актуально-длительным. Таким образом, контексты возможной вариативности составляют лишь определенную долю употреблений НСВ. В пользу такого объяснения свидетельствуют случаи отклонения от тенденции к преобладанию вин. п. при $\mathrm{HCB}$, наблюдаемые у имперфективных глаголов, для которых значение многократности является основным (нарывать <цветов>, накупать <подарков>).

\footnotetext{
${ }^{1}$ На диаграмме типа «ящик с усами» х обозначает среднее арифметическое, а средняя линия ящика — медиану для каждого представленного ряда данных.
} 
Отклонение от тенденции к оформлению объекта вин. падежом наблюдается также для нескольких глаголов с абстрактной семантикой, реферирующих преимущественно к постоянным ситуациям: подбавлять, прибавлять (2), придавать, см. (11).

(11) Западные инвесторы очень консервативны, проверенные юрисдикиии придают им уверенности. [Неоклеус Андреас. Кипру можно верить // «Эксперт», 2013]

В случаях типа (11) наблюдается употребление род. падежа за пределами контекстов нейтрализации видового противопоставления. Такие примеры не противоречат утверждению о несочетаемости род. партитивного и актуально-длительного значения НСВ: структура ситуации не предполагает развития действия, направленного на достижение некоторого предела (результата), выражаемого СВ, обозначаемая глаголом $\mathrm{HCB}$ ситуация результативна в любой момент своего существования.

\section{3 Актуально-длительное значение НСВ и употребление родительного партитивного}

Как было отмечено выше, в литературе постулируется невозможность употребления род. партитивного при глаголах НСВ в актуально-длительном значении. Однако данные НКРЯ и рунета показывают, что имперфективные корреляты некоторых глаголов комплетивно-партитивного и отделительно-партитивного СД, а также кумулятивного СД с семантикой постепенного накопления результата («тип $2 »$, см. выше) демонстрируют примеры сочетания с род. партитивным в том числе при употреблении в актуально-длительном значении, см. (12)-(14).

(12) И пока он набирает из колонки воды в мутно-желтую большую банку, а потом протирает мокрой тряпкой памятник, я смотрю на небо, вижу его прохладную голубизну, вижу его слабое, подтаявшее по краям облачко... [Ирина Муравьева. Ляля, Наташа, Тома (1991)]

(13) - Необыкновенные? - воскликнул я с видом любопытства, подливая ему чая.

[М. Ю. Лермонтов. Герой нашего времени (1839-1841)]

(14) - лениво отозвался Петров, щедро отсыпая на газетный лоскуток злющего самосаду. [Анатолий Ткаченко. В заливе измены (1975) // «Огонек», 1961]

Видовые пары глаголов комплетивно-партитивного и отделительно-партитивного способов действия, а также кумулятивные глаголы с префиксом на-, демонстрируют сходства в семантике видового противопоставления. Глагол СВ в таких парах глаголов не указывает на достижение естественного предела. Ю. С. Маслов выделял в отдельную группу пары глаголов, обозначающих ситуации, для которых «нет возможности выделить “критическую точку", знаменующую переход к новому состоянию, границу, отделяющую новое состояние от старого» [11: 86] (для обозначения видовых пар с указанным типом семантического соотношения используется термин «градативы» [12], или «градационные пары» [21]). Как представляется, обнаруживается сходство между градационными глаголами $\mathrm{HCB}$ и упомянутыми выше глаголами, обозначающими постоянные ситуации (см. (11)): в обоих случаях рассматриваемые контексты НСВ не являются контекстами нейтрализации видового противопоставления, при этом обозначаемая длительная ситуация может рассматриваться как результативная в любой произвольный момент времени.

\section{4 Выводы}

Приведенные выше наблюдения показывают, что использование формы род. падежа с партитивной семантикой как средства оформления прямого дополнения при имперфективных глаголах оказывается сложнее, чем принято считать в литературе. Среди основных итогов исследования можно отметить следующие.

Употребление род. падежа при имперфективных глаголах не представляет собой редкое или маргинальное явление: соответствующее употребление наблюдается для видовых коррелятов 
более чем половины глаголов СВ, демонстрирующих примеры сочетания с род. падежом в НКРЯ и рунете.

Доли имперфективных лексем, демонстрирующих примеры генитивного управления, неодинаковы в различных префиксальных группах и коррелируют с уровнем имперфективируемости, а также принципиальной с употребительностью (и частотностью) конкретных префиксальных лексем.

Данные о количественном соотношении род. и вин. падежей при глаголах СВ и НСВ свидетельствуют о преобладании вин. падежа при имперфективных глаголах, что, как представляется, является следствием ограниченной сферы употребления род. партитивного, сочетающегося только с определенными значениями из семантического спектра $\mathrm{HCB}$, в частности, со значениями, реализуемыми в контекстах нейтрализации видового противопоставления.

Употребление род. падежа при имперфективных глаголах чувствительно к семантическим особенностям НСВ и к семантике видового противопоставления, при этом рассматриваемая проблематика оказывается шире, чем, как правило, обсуждается в литературе. Так, например, обнаружено, что употребление род. партитивного не ограничивается контекстами нейтрализации видового противопоставления: данные НКРЯ и рунета позволяют сделать вывод о возможности употребления род. падежа при имперфективных глаголах, обозначающих постоянные ситуации. Также при ряде имперфективных глаголов кумулятивного, комплетивно-партитивного и отделительно-партитивного СД, входящих в градационные видовые пары, возможно употребление род. падежа в случаях, если НСВ имеет актуально-длительное значение, что постулируется в литературе как невозможное. Наконец, нестандартной семантикой видового противопоставления может объясняться сниженная способность глаголов прерывисто-смягчительного СД, рассматриваемых как результат имперфективации глаголов делимитативного СД, к употреблению с род. падежом.

\section{Благодарности}

Исследование выполнено при финансовой поддержке РФФИ в рамках научного проекта № 19-312-60006 «Прямое дополнение и аспектуальные характеристики славянского глагола».

\section{Acknowledgements}

The reported study was funded by the Russian Foundation for Basic Research (RFBR), project number 19-312-60006.

\section{References}

[1] Chuikova Oksana Iu. (2020) On the secondary imperfectivation of po-perfectives in Russian [Ob osobennostyakh vtorichnoj imperfektivatsii glagolov s prefiksom po- v russkom yazyke], Computational Linguistics and Intellectual Technologies. Papers from the Annual International Conference "Dialogue", vol. 19 (26), pp. $160-176$.

[2] Chuikova Oksana Iu. (2020) Towards the issue on the interaction of verbal aspect and the case of direct object in Russian [K voprosu o vzaimodejstvii glagol'nogo vida i padezha pryamogo dopolneniya $\mathrm{v}$ russkom yazyke], Proceedings of the 7th International Aspectological Conference "Interrelation between Aspect and Adjacent Categories", May 5-8, 2020 [Vzaimodejstvie aspekta so smezhnymi kategoriyami. Materialy VII Mezhdunarodnoj konferentsii Komissii po aspektologii Mezhdunarodnogo komiteta slavistov (Sankt-Peterburg, 5-8 maya 2020 goda).], Izd-vo RGPU im. A. I. Gertsena, St. Petersburg, pp. 81-93.

[3] Evgenieva Anastasija P. (ed.) (1981-1984), Dictionary of Russian Language in 4 volumes [Slovar' russkogo jazyka v 4 tomah], 2nd ed. Academy of Science of USSR, Institute of Russian Language, Moscow, available at: http://feb-web.ru/feb/mas/mas-abc/14/ma239217.htm

[4] Fedotov Maksim L., Chuikova Oksana Ju. (2013), On the definition of limitative aspectual meaning and on the features of "delimitative" verbs in Russian [K opredeleniiu aspektual'nogo znacheniia delimitativa i voprosu ob osobennostiakh "delimitativnoi" derivatsii russkogo glagola], E. I. Grekhova (ed.) From the past to the future. Collection of articles and memoirs to the $100^{\text {th }}$ anniversary of prof. Yu. S. Maslov [Iz proshlogo v budushchee. Sbornik statei i vospominanii k 100-letiiu Yu. S. Maslova], SPbU Publ., St. Petersburg, pp. 153-203.

[5] Filip Hana (2005), Measures and indefinites // Reference and Quantification: The Partee Effect, CSLI Press, Stanford, California, pp. 229-289. 
[6] Glovinskaya Marina Ya. (2001) Polysemy and Synonymy in the Tense-Aspect System of the Russian Verb [Mnogoznachnost' i sinonimiya v vido-vremennoj sisteme russkogo glagola], Azbukovnik Publ., Moscow.

[7] Gorbova Elena V. (2019), To the Restriction on Imperfectivation: To the Restriction on Imperfectivation: are Russian Verbs of Perfective Aktionsarten Imperfectivable? [K ogranicheniyu na imperfektivaciyu: imperfektiviruyutsya li russkie glagoly perfektivnykh sposobov dejstviya?], Gerasimov D. V., Dmitrenko S. Yu., Zaika N. M. (eds.) Collection of articles to the $85^{\text {th }}$ anniversary of V. S. Khrakovskij [Sbornik statej k 85letiyu V. S. Khrakovskogo], Yazyki russkoj kul'tury Publ., Moscow, pp. 98-115.

[8] Gorbova Elena V., Chuikova Oksana Iu. (2020) Aktionsarten and the secondary imperfectivation (the case of po-, pro-, $u$-verbs) [Sposoby dejstviya russkogo glagola i vtorichnaya imperfektivatsiya (na primere pristavochnykh grupp glagolov na po-, pro-, $u$-)], Proceedings of the 7th International Aspectological Conference "Interrelation between Aspect and Adjacent Categories", May 5-8, 2020 [Vzaimodejstvie aspekta so smezhnymi kategoriyami. Materialy VII Mezhdunarodnoj konferentsii Komissii po aspektologii Mezhdunarodnogo komiteta slavistov (Sankt-Peterburg, 5-8 maya 2020 goda).], Izd-vo RGPU im. A. I. Gertsena, St. Petersburg, pp. 136-148.

[9] Gorbova Elena V., Chuikova Oksana Iu., Sharygina Sofya S. (2021), Imperfectivability of Russian prefixal perfectives: regularity and peculiarities [Imperfektiviruemost' russkikh pristavochnykh perfektivov: regulyarnost' i specifika], Topics in the study of language [Voprosy Jazykoznanija], no. 4, pp. 91-130.

[10] Karcevskij Sergey J. (1962), Aspect [Vid], Issues in the Russian Aspect [Voprosy glagol'nogo vida], Izd-vo Inostrannoi Literatury, Moscow, pp. 218-230.

[11] Maslov Iury S. (2004), Selected works. Aspectology. General Linguistics [Izbrannye trudy: Aspektologiia. Obshchee iazykoznanie], Yazyki slavyanskikh kul'tur, Moscow.

[12] Paducheva Elena V. (1996), Semantic studies: Semantics of tense and aspect in Russian; Semantics of the narrative [Semanticheskie issledovaniya: Semantika vremeni i vida v russkom yazyke. Semantika narrative], Yazyki russkoj kul'tury Publ., Moscow.

[13] Paducheva Elena V. (1998), On non-compatibility of partitive and imperfective in Russian, Theoretical linguistics, vol. 24 (1), pp. 73-82.

[14] Pazel'skaya Anna G., Tatevosov Sergey G. (2008), Verbal Noun and the Structure of Russian verb [Otglagol'noe imya i struktura russkogo glagola], Verbal Derivation Research [Issledovaniya po glagol'noj derivatsii], Yazyki slavyanskikh kul'tur, Moscow, pp. 348-379.

[15] Pereltsvaig Asya (2006), Small nominlas, Natural Language and Linguistic Theory, vol. 24, pp. $433-500$.

[16] Romanova Eugenia (2006), Constructing Perfectivity in Russian: Ph.D. Dissertation, University of Tromsø, Tromsø.

[17] Russian National Corpus [Nacional'nyi korpus russkogo jazyka] (2003-2019), available at: http://www.ruscorpora.ru

[18] Shatunovskij Ilya B. (2009), Problems of the Russian Aspect [Problemy russkogo vida], Yazyki slavyanskikh kul'tur Publ., Moscow.

[19] Shelyakin Mikhail (2008), Category of aspectuality of the Russian verb [Kategoriya aspektual'nosti russkogo glagola], URSS Publ., Moscow.

[20] Wierzbicka Anna (1967), On the semantics of the verbal aspect in Polish // To honor Roman Jakobson, Mouton, The Hague-Paris, pp. 2231-2249.

[21] Zalizniak Anna A., Shmelev Aleksey D. (2000), Introduction to the study of Russian aspect [Vvedenie v russkuyu aspektologiyu], Yazyki russkoj kul'tury Publ., Moscow. 
Приложение А. Соотношение родительного и винительного падежей при СВ и НСВ с префиксом на-

\begin{tabular}{|c|c|c|c|c|c|c|c|c|}
\hline & \multicolumn{4}{|l|}{$\mathrm{CB}$} & \multicolumn{4}{|l|}{$\mathrm{HCB}$} \\
\hline & $\begin{array}{l}\text { РП по } \\
\text { НКРЯ }\end{array}$ & $\begin{array}{l}\text { ВП по } \\
\text { НКРЯ }\end{array}$ & $\begin{array}{l}\text { Отношение } \\
\text { шансов }\end{array}$ & \begin{tabular}{|l|} 
суммa \\
CB
\end{tabular} & $\begin{array}{l}\text { РП по } \\
\text { НКРЯ }\end{array}$ & $\begin{array}{l}\text { ВП по } \\
\text { НКРЯ }\end{array}$ & $\begin{array}{l}\text { Отношение } \\
\text { шансов }\end{array}$ & $\begin{array}{l}\text { cymma } \\
\text { HCB }\end{array}$ \\
\hline налить (1) & 1822 & 470 & 3,88 & 2292 & 362 & 1075 & 0,34 & 1437 \\
\hline набрать (1) & 1148 & 100 & 11,48 & 1248 & 160 & 424 & 0,38 & 584 \\
\hline накупить & 514 & 28 & 18,36 & 542 & 21 & 9 & 2,33 & 30 \\
\hline нacbínamb (2) & 346 & 122 & 2,84 & 468 & 31 & 150 & 0,21 & 181 \\
\hline нарезать (1) & 85 & 201 & 0,42 & 286 & 1 & 65 & 0,02 & 66 \\
\hline нарвать (1) & 201 & 12 & 16,75 & 213 & 4 & 0 & - & 4 \\
\hline натаскать (1) & 187 & 13 & 14,38 & 200 & 6 & 7 & 0,86 & 13 \\
\hline наnycmumb & 167 & 26 & 6,42 & 193 & 25 & 30 & 0,83 & 55 \\
\hline Haneyb & 164 & 11 & 14,91 & 175 & 1 & 0 & - & 1 \\
\hline наделать (1) & 162 & 9 & 18,00 & 171 & 1 & 1 & 1,00 & 2 \\
\hline набросать & 106 & 43 & 2,47 & 149 & 5 & 15 & 0,33 & 20 \\
\hline нагнать (4) & 85 & 54 & 1,57 & 139 & 15 & 98 & 0,15 & 113 \\
\hline наломать & 111 & 9 & 12,33 & 120 & 2 & 2 & 1,00 & 4 \\
\hline нажить & 26 & 84 & 0,31 & 110 & 15 & 95 & 0,16 & 110 \\
\hline нарезать (2) & 75 & 34 & 2,21 & 109 & 1 & 13 & 0,08 & 14 \\
\hline нагнать (3) & 64 & 41 & 1,56 & 105 & 4 & 31 & 0,13 & 35 \\
\hline наложить & 75 & 10 & 7,50 & 85 & 31 & 143 & 0,22 & 174 \\
\hline навалить (2) & 60 & 9 & 6,67 & 69 & 8 & 21 & 0,38 & 29 \\
\hline натацить & 55 & 8 & 6,88 & 63 & 6 & 7 & 0,86 & 13 \\
\hline нацедить & 56 & 3 & 18,67 & 59 & 4 & 9 & 0,44 & 13 \\
\hline наскрести (2) & 43 & 7 & 6,14 & 50 & 2 & 6 & 0,33 & 8 \\
\hline навешать & 36 & 11 & 3,27 & 47 & 3 & 19 & 0,16 & 22 \\
\hline натереть & 15 & 29 & 0,52 & 44 & 1 & 14 & 0,07 & 15 \\
\hline набить (1) & 39 & 4 & 9,75 & 43 & 5 & 32 & 0,16 & 37 \\
\hline надергать (1) & 41 & 1 & 41,00 & 42 & 1 & 3 & 0,33 & 4 \\
\hline накопать (2) & 36 & 5 & 7,20 & 41 & 1 & 1 & 1 & 2 \\
\hline намести (2) & 37 & 3 & 12,33 & 40 & 4 & 4 & 1 & 8 \\
\hline насовать (1) & 34 & 6 & 5,67 & 40 & 1 & 0 & - & 1 \\
\hline навалить (1) & 16 & 23 & 0,70 & 39 & 4 & 16 & 0,25 & 20 \\
\hline нашить & 35 & 4 & 8,75 & 39 & 2 & 2 & 1 & 4 \\
\hline нанести (1) & 34 & 4 & 8,50 & 38 & 1 & 2 & 0,50 & 3 \\
\hline накачать & 15 & 12 & 1,25 & 27 & 1 & 51 & 0,02 & 52 \\
\hline напилить & 21 & 4 & 5,25 & 25 & 1 & 0 & - & 1 \\
\hline
\end{tabular}




\begin{tabular}{|c|c|c|c|c|c|c|c|c|}
\hline настлать (1) & 22 & 3 & 7,33 & 25 & 4 & 7 & 0,57 & 11 \\
\hline навалить (3) & 24 & 0 & - & 24 & 3 & 0 & - & 3 \\
\hline нагрести & 21 & 3 & 7,00 & 24 & 3 & 14 & 0,21 & 17 \\
\hline нагулять & 13 & 9 & 1,44 & 22 & 4 & 26 & 0,15 & 30 \\
\hline навесить & 13 & 7 & 1,86 & 20 & 3 & 19 & 0,16 & 22 \\
\hline намазать & 4 & 14 & 0,29 & 18 & 1 & 42 & 0,02 & 43 \\
\hline набрать (4) & 7 & 6 & 1,17 & 13 & 2 & 6 & 0,33 & 8 \\
\hline настелить & 12 & 0 & - & 12 & 4 & 7 & 0,57 & 11 \\
\hline набить (2) & 7 & 4 & 1,75 & 11 & 1 & 2 & 0,50 & 3 \\
\hline надуть & 7 & 4 & 1,75 & 11 & 1 & 3 & 0,33 & 4 \\
\hline накласть & 10 & 1 & 10,00 & 11 & 31 & 143 & 0,22 & 174 \\
\hline намять & 9 & 2 & 4,50 & 11 & 1 & 3 & 0,33 & 4 \\
\hline наметать 2 (1) & 6 & 4 & 1,50 & 10 & 1 & 1 & 1 & 2 \\
\hline настричь & 8 & 2 & 4,00 & 10 & 1 & 1 & 1 & 2 \\
\hline надергать (2) & 8 & 0 & - & 8 & 1 & 0 & - & 1 \\
\hline наменять (2) & 8 & 0 & - & 8 & 2 & 0 & - & 2 \\
\hline наскрести (1) & 6 & 0 & - & 6 & 1 & 1 & 1 & 2 \\
\hline нажсечв & 3 & 1 & 3,00 & 4 & 1 & 0 & - & 1 \\
\hline накатать (1) & 2 & 1 & 2,00 & 3 & 2 & 1 & 2 & 3 \\
\hline Hanacmu & 3 & 0 & - & 3 & 1 & 0 & - & 1 \\
\hline настрелять & 3 & 0 & $\overline{-}$ & 3 & 1 & 0 & - & 1 \\
\hline Haмbimb (1) & 1 & 1 & 1,00 & 2 & 2 & 1 & 2 & 3 \\
\hline накатить1 & 1 & 0 & - & 1 & 2 & 1 & 2 & 3 \\
\hline Среднее & $\begin{array}{l}109,0 \\
9\end{array}$ & 26,11 & 6,80 & 135,2 & 14,34 & 46,84 & 0,59 & 61,18 \\
\hline Медиана & 30 & 6 & & 39,5 & 2 & 6,5 & & 9,5 \\
\hline $\begin{array}{l}\text { Стандартное } \\
\text { отклонение }\end{array}$ & $\begin{array}{l}288,9 \\
3\end{array}$ & 69,71 & & $\begin{array}{l}349,0 \\
2\end{array}$ & 52,21 & 154,30 & & $\begin{array}{l}206,0 \\
6\end{array}$ \\
\hline Сумма & 6109 & 1462 & & 7571 & 803 & 2623 & & 3426 \\
\hline \multicolumn{4}{|l|}{ хи-квадрат } & & & & & \\
\hline & $\mathbf{P \Pi}$ & ВП & Total & & & & & \\
\hline$\overline{C B}$ & 6109 & 1462 & 7571 & & & & & \\
\hline HCB & 803 & 2623 & 3426 & & & & & \\
\hline Total & 6912 & 4085 & 10997 & & & & & \\
\hline \multicolumn{4}{|c|}{$\begin{array}{l}\text { Различие статистически значимо: } \\
\chi^{2}=3308,754, \mathrm{p}<<0,01 .\end{array}$} & & & & & \\
\hline
\end{tabular}




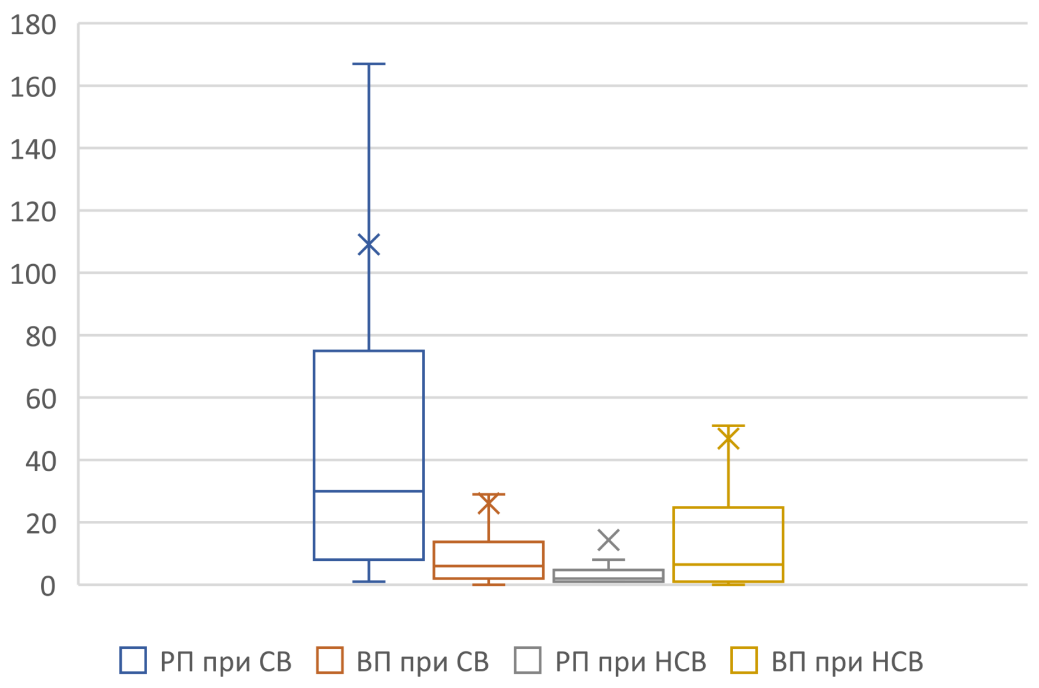

Рисунок А: Частоты конструкций с родительным и винительным падежами при СВ и НСВ с префиксом на-

Приложение Б. Соотношение родительного и винительного падежей при СВ и НСВ с префиксом под-

\begin{tabular}{|c|c|c|c|c|c|c|c|c|}
\hline & \multicolumn{4}{|l|}{$\mathrm{CB}$} & \multicolumn{4}{|l|}{ HCB } \\
\hline & $\begin{array}{l}\text { РП по } \\
\text { НКРЯ }\end{array}$ & $\begin{array}{l}\text { ВП по } \\
\text { НКРЯ }\end{array}$ & $\begin{array}{l}\text { Отношение } \\
\text { шансов }\end{array}$ & $\begin{array}{l}\text { Сумма } \\
\text { CВ }\end{array}$ & $\begin{array}{l}\text { РП по } \\
\text { НКРЯ }\end{array}$ & $\begin{array}{l}\text { ВП по } \\
\text { НКРЯ }\end{array}$ & $\begin{array}{l}\text { Отношение } \\
\text { шансов }\end{array}$ & $\begin{array}{l}\text { Cумma } \\
\text { HCB }\end{array}$ \\
\hline подбросить & 175 & 26 & 6,73 & 201 & 41 & 134 & 0,31 & 175 \\
\hline nodcbínamb & 127 & 43 & 2,95 & 170 & 30 & 59 & 0,51 & 89 \\
\hline подлить & 120 & 16 & 7,50 & 136 & 154 & 167 & 0,92 & 321 \\
\hline nоддаmь (1) & 123 & 2 & 61,50 & 125 & 11 & 75 & 0,15 & 86 \\
\hline поднести & 88 & 21 & 4,19 & 109 & 27 & 69 & 0,39 & 96 \\
\hline подкинуть & 86 & 18 & 4,78 & 104 & 14 & 54 & 0,26 & 68 \\
\hline подбавить & 73 & 2 & 36,50 & 75 & 46 & 15 & 3,07 & 61 \\
\hline подложить & 59 & 10 & 5,90 & 69 & 37 & 165 & 0,22 & 202 \\
\hline подкопить & 36 & 5 & 7,20 & 41 & 2 & 5 & 0,40 & 7 \\
\hline подмешать & 18 & 21 & 0,86 & 39 & 9 & 58 & 0,16 & 67 \\
\hline подпустить (2) & 26 & 8 & 3,25 & 34 & 2 & 1 & 2,00 & 3 \\
\hline подкупить & 12 & 5 & 2,40 & 17 & 1 & 4 & 0,25 & 5 \\
\hline подпустить (3) & 13 & 3 & 4,33 & 16 & 5 & 1 & 5,00 & 6 \\
\hline подкачать & 1 & 3 & 0,33 & 4 & 1 & 9 & 0,11 & 10 \\
\hline подкосить & 1 & 1 & 1,00 & 2 & 1 & 1 & 1,00 & 2 \\
\hline Среднее & 63,87 & 12,27 & 9,96 & 76,13 & 25,40 & 54,47 & 0,98 & 79,87 \\
\hline Медиана & 59 & 8 & & 69 & 11 & 54 & & 67 \\
\hline $\begin{array}{l}\text { Стандартное } \\
\text { отклонение }\end{array}$ & 54,55 & 11,87 & & 62,38 & 38,98 & 59,20 & & 91,17 \\
\hline Сумма & 958 & 184 & & 1142 & 381 & 817 & & 1198 \\
\hline
\end{tabular}




\begin{tabular}{|l|l|l|l|}
\hline хи-квадрат \\
\hline & PП & ВП & Total \\
\hline CВ & 958 & 184 & 1142 \\
\hline HCB & 381 & 817 & 1198 \\
\hline Total & 1339 & 1001 & 2340 \\
\hline $\begin{array}{l}\text { Различие статистически значимо: } \\
\chi^{2}=645,834, p<<0,01 .\end{array}$ \\
\hline
\end{tabular}

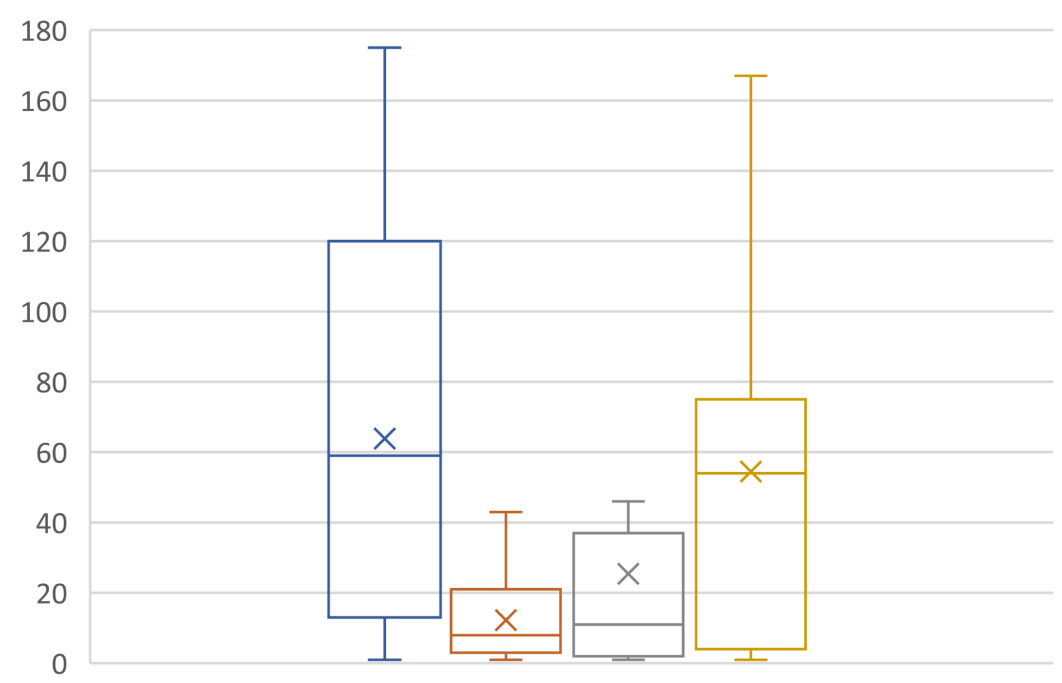

$\square$ РПпри СВ $\square$ ВПпри СВ $\square$ РПпри НСВ $\square$ ВПпри НСВ

Рисунок Б: Частоты конструкций с родительным и винительным падежами при СВ и НСВ с префиксом под-

Приложение В. Соотношение родительного и винительного падежей при СВ и НСВ с префиксом при-

\begin{tabular}{|l|l|l|l|l|l|l|l|l|}
\hline & \multicolumn{9}{|l|}{ СВ } & \multicolumn{1}{l}{ НСВ } \\
\hline & $\begin{array}{l}\text { РП по } \\
\text { НКРЯ }\end{array}$ & $\begin{array}{l}\text { ВП по } \\
\text { НКР }\end{array}$ & $\begin{array}{l}\text { Отношение } \\
\text { шансов }\end{array}$ & $\begin{array}{l}\text { Сумма } \\
\text { СВ }\end{array}$ & $\begin{array}{l}\text { РП по } \\
\text { НКР }\end{array}$ & $\begin{array}{l}\text { ВП по } \\
\text { НКР }\end{array}$ & $\begin{array}{l}\text { Отношение } \\
\text { шансов }\end{array}$ & $\begin{array}{l}\text { Сумма } \\
\text { НСВ }\end{array}$ \\
\hline прибавить (2) & 835 & 166 & 5,03 & 1001 & $\mathbf{2 5 5}$ & 85 & 3,00 & 340 \\
\hline прислать & 31 & 177 & 0,18 & 208 & 17 & 598 & 0,03 & 615 \\
\hline придать & 139 & 66 & 2,11 & 205 & $\mathbf{7 3}$ & 61 & 1,20 & 134 \\
\hline прихватить & 47 & 139 & 0,34 & 186 & 5 & 21 & 0,24 & 26 \\
\hline принять & 28 & 150 & 0,19 & 178 & 1 & 33 & 0,03 & 34 \\
\hline прикупить & 63 & 61 & 1,03 & 124 & 6 & 33 & 0,18 & 39 \\
\hline пригубить & 28 & 65 & 0,43 & 93 & 1 & 14 & 0,07 & 15 \\
\hline прибавить (1) & 44 & 28 & 1,57 & 72 & 22 & 40 & 0,55 & 62 \\
\hline приготовить & 15 & 19 & 0,79 & 34 & 1 & 13 & 0,08 & 14 \\
\hline прихлебнуть & 20 & 6 & 3,33 & 26 & 5 & 406 & 0,01 & 411 \\
\hline примешать & 8 & 11 & 0,73 & 19 & 3 & 69 & 0,04 & 72 \\
\hline
\end{tabular}




\begin{tabular}{|c|c|c|c|c|c|c|c|c|}
\hline прирезать & 9 & 6 & 1,5 & 15 & 1 & 2 & 0,50 & 3 \\
\hline прикопить & 7 & 2 & 3,5 & 9 & 1 & 8 & 0,13 & 9 \\
\hline припустить & 6 & 1 & 6 & 7 & 3 & 1 & 3 & 4 \\
\hline прикушать & 6 & 0 & - & 6 & 1 & 0 & - & 1 \\
\hline приработать & 1 & 0 & - & 1 & 1 & 1 & 1 & 2 \\
\hline Среднее & 80,44 & 56,06 & 1,91 & 136,5 & 24,75 & 86,56 & 0,67 & 111,31 \\
\hline Медиана & 24 & 23,5 & & 53 & 3 & 27 & & 30 \\
\hline $\begin{array}{l}\text { Стандартное } \\
\text { отклонение }\end{array}$ & $\begin{array}{l}204,0 \\
5\end{array}$ & 65,35 & & 243,21 & 64,00 & 167,91 & & 181,73 \\
\hline Сумма & 1287 & 897 & & 2184 & 396 & 1385 & & 1781 \\
\hline \multicolumn{4}{|l|}{ хи-квадрат } & & & & & \\
\hline & $\mathbf{P I}$ & BП & Total & & & & & \\
\hline при- CB & 1287 & 897 & 2184 & & & & & \\
\hline при- НСВ & 396 & 1385 & 1781 & & & & & \\
\hline Total & 1683 & 2282 & 3965 & & & & & \\
\hline \multicolumn{4}{|c|}{$\begin{array}{l}\text { Различие статистически значимо: } \\
\chi^{2}=539,187, \mathrm{p}<<0,01 \text {. }\end{array}$} & & & & & \\
\hline
\end{tabular}

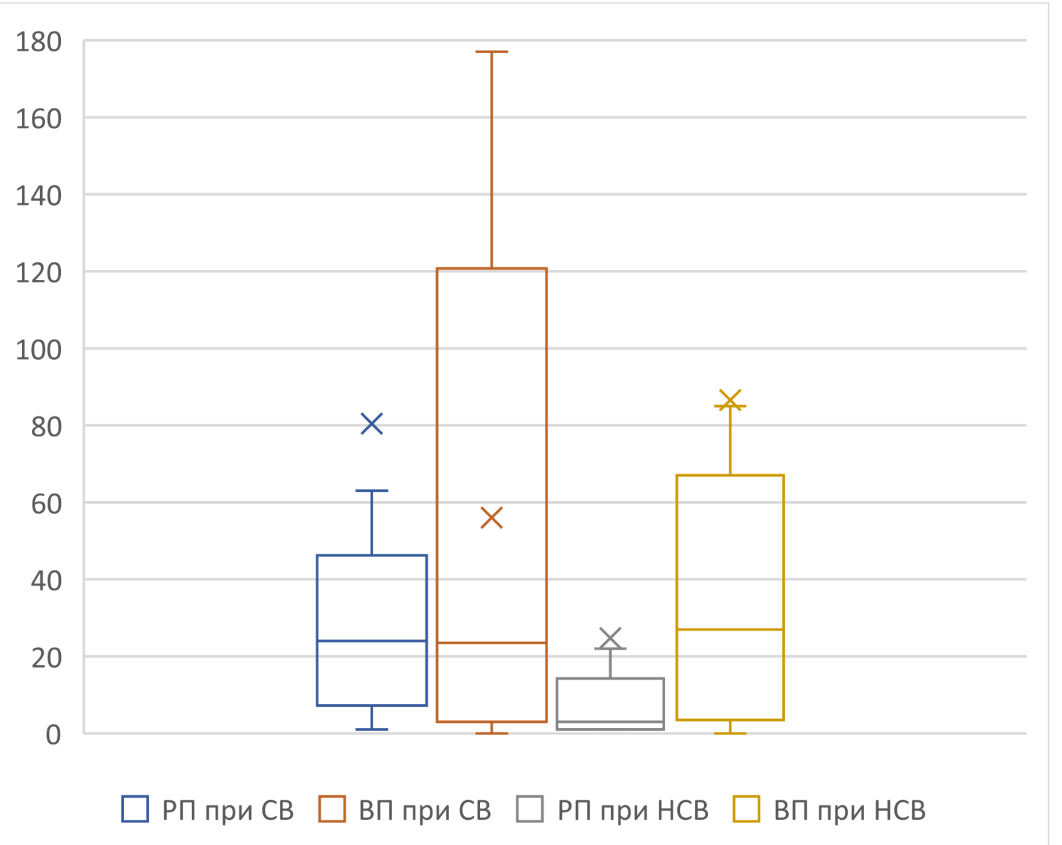

Рисунок В: Частоты конструкций с родительным и винительным падежами при СВ и НСВ с префиксом $п р и$ - 
Приложение Г. Соотношение родительного и винительного падежей при СВ и НСВ с префиксом до-

\begin{tabular}{|c|c|c|c|c|c|c|c|c|}
\hline & \multicolumn{4}{|l|}{ CB } & \multicolumn{4}{|l|}{ HCB } \\
\hline & $\begin{array}{l}\text { РП по } \\
\text { НКРЯ }\end{array}$ & $\begin{array}{l}\text { ВП по } \\
\text { НКРЯ }\end{array}$ & $\begin{array}{l}\text { Отношение } \\
\text { шансов }\end{array}$ & Сумма & $\begin{array}{l}\text { РП по } \\
\text { НКРЯ }\end{array}$ & $\begin{array}{l}\text { ВП по } \\
\text { НКРЯ }\end{array}$ & $\begin{array}{l}\text { Отношение } \\
\text { шансов }\end{array}$ & Сумма \\
\hline добавить & 188 & 242 & 0,78 & 430 & 71 & 233 & 0,30 & 304 \\
\hline добрать & 7 & 7 & 1 & 14 & 5 & 17 & 0,29 & 22 \\
\hline добыть (1) & 40 & 180 & 0,22 & 220 & 4 & 183 & 0,02 & 187 \\
\hline добыть (2) & 5 & 32 & 0,16 & 37 & 2 & 438 & 0,00 & 440 \\
\hline долить & 52 & 17 & 3,06 & 69 & 18 & 39 & 0,46 & 57 \\
\hline доставить & 3 & 62 & 0,05 & 65 & 1 & 11 & 0,09 & 12 \\
\hline досыnamb & 4 & 1 & 4 & 5 & 3 & 3 & 1 & 6 \\
\hline Среднее & 42,71 & 77,29 & 1,32 & 120 & 14,86 & 132 & 0,31 & 146,86 \\
\hline Медиана & 7 & 32 & & 65 & 4 & 39 & & 57 \\
\hline $\begin{array}{l}\text { Стандартное } \\
\text { отклонение }\end{array}$ & 67,05 & 95,18 & & 154,42 & 25,41 & 163,09 & & 170,26 \\
\hline Сумма & 299 & 541 & & 840 & 104 & 924 & & 1028 \\
\hline \multicolumn{4}{|l|}{ хи-квадрат } & & & & & \\
\hline & PП & ВП & Total & & & & & \\
\hline$\overline{C B}$ & 299 & 541 & 840 & & & & & \\
\hline HCB & 104 & 924 & 1028 & & & & & \\
\hline Total & 403 & 1465 & 1868 & & & & & \\
\hline \multicolumn{4}{|c|}{$\begin{array}{l}\text { Различие статистически значимо: } \\
\chi^{2}=175,857, \mathrm{p}<<0,01 .\end{array}$} & & & & & \\
\hline
\end{tabular}

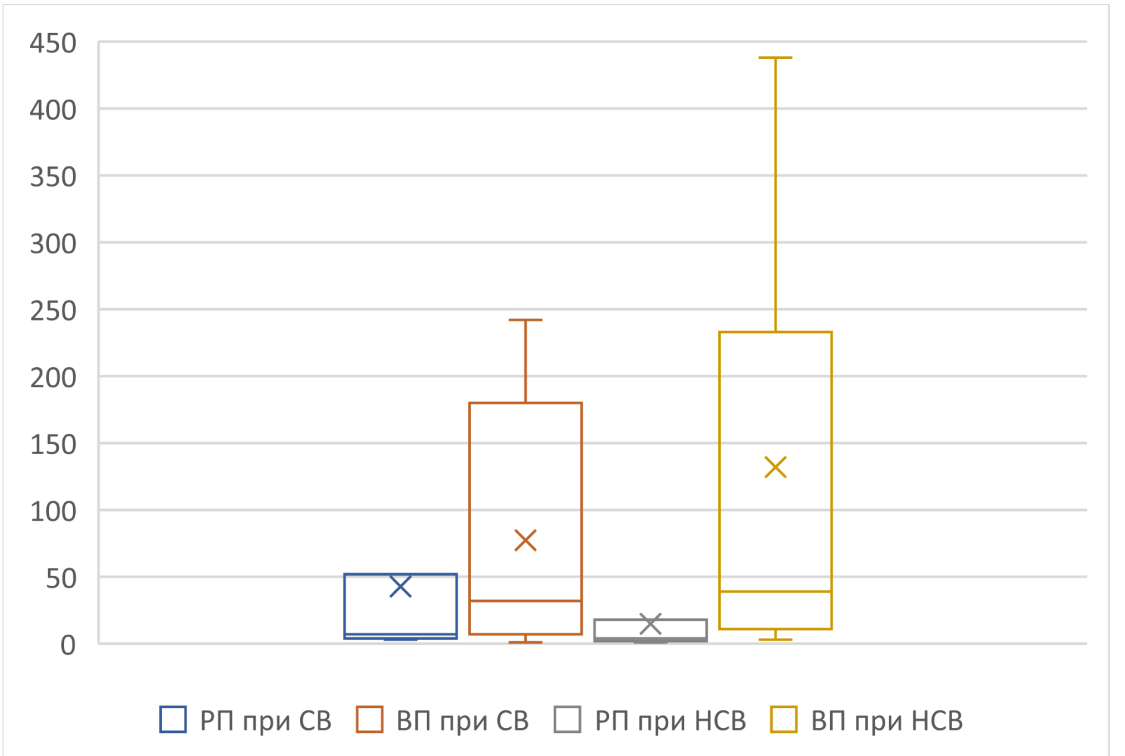

Рисунок Г: Частоты конструкций с родительным и винительным падежами при СВ и НСВ с префиксом до- 
Приложение Д. Соотношение родительного и винительного падежей при СВ и НСВ с префиксом от-

\begin{tabular}{|c|c|c|c|c|c|c|c|c|}
\hline & \multicolumn{4}{|l|}{$\mathrm{CB}$} & \multicolumn{4}{|l|}{$\mathrm{HCB}$} \\
\hline & $\begin{array}{l}\text { РП по } \\
\text { НКРЯ }\end{array}$ & $\begin{array}{l}\text { ВП по } \\
\text { НКРЯ }\end{array}$ & $\begin{array}{l}\text { Отношение } \\
\text { шансов }\end{array}$ & $\begin{array}{l}\text { Сумма } \\
\text { CВ }\end{array}$ & $\begin{array}{l}\text { РП по } \\
\text { НКРЯ }\end{array}$ & $\begin{array}{l}\text { ВП по } \\
\text { НКРЯ }\end{array}$ & $\begin{array}{l}\text { Отношение } \\
\text { шансов }\end{array}$ & $\begin{array}{l}\text { Сумма } \\
\text { НСB }\end{array}$ \\
\hline отведать (1) & 323 & 60 & 5,38 & 383 & 9 & 14 & 0,64 & 23 \\
\hline отведать (2) & 101 & 7 & 14,43 & 108 & 7 & 1 & 7,00 & 8 \\
\hline откуиать & 110 & 23 & 4,78 & 133 & 2 & 1 & 2,00 & 3 \\
\hline отлить & 14 & 7 & 2,00 & 21 & 4 & 40 & 0,10 & 44 \\
\hline omnumb & 73 & 42 & 1,74 & 115 & 7 & 72 & 0,10 & 79 \\
\hline omcbinamb & 41 & 4 & 10,25 & 45 & 5 & 9 & 0,56 & 14 \\
\hline отхлебнуть & 153 & 40 & 3,83 & 193 & 6 & 127 & 0,05 & 133 \\
\hline отцедить & 0 & 11 & 0,00 & 11 & 1 & 8 & 0,13 & 9 \\
\hline Среднее & 101,88 & 24,25 & $5, \mathbf{3 0}$ & 126,13 & 5,13 & 34,00 & 1,32 & 39,13 \\
\hline Медиана & 87,00 & 17,00 & & 111,50 & 5,50 & 11,50 & & 18,50 \\
\hline $\begin{array}{l}\text { Стандартное } \\
\text { отклонение }\end{array}$ & 102,97 & 20,78 & & 120,62 & 2,70 & 44,73 & & 45,51 \\
\hline Сумма & 815 & 194 & & 1009 & 41 & 272 & & 313 \\
\hline \multicolumn{4}{|l|}{ хи-квадрат } & & & & & \\
\hline & PII & ВП & Total & & & & & \\
\hline CB & 815 & 194 & 1009 & & & & & \\
\hline HCB & 41 & 272 & 313 & & & & & \\
\hline Total & 856 & 466 & 1322 & & & & & \\
\hline \multicolumn{4}{|c|}{$\begin{array}{l}\text { Различие статистически значимо: } \\
\chi^{2}=476,388, \mathrm{p}<<0,01 .\end{array}$} & & & & & \\
\hline
\end{tabular}

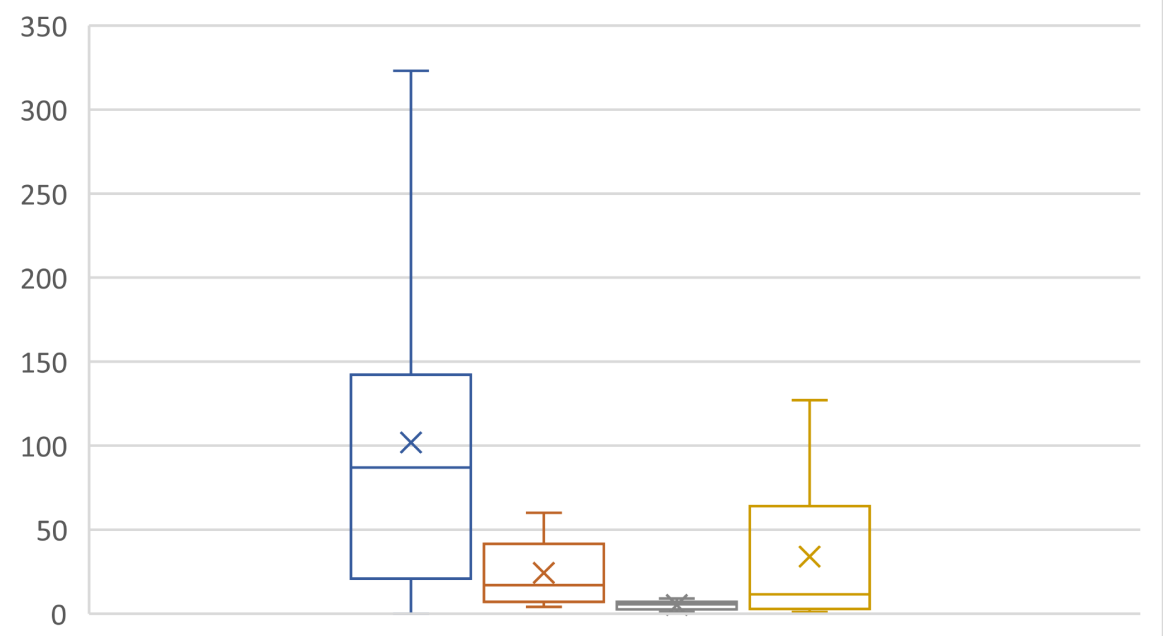

1

$\square$ РП при СВ $\square$ ВПпри СВ $\square$ РПпри НСВ $\square$ ВПпри НСВ

Рисунок Д: Частоты конструкций с родительным и винительным падежами при СВ и НСВ с префиксом от- 